\title{
An analysis of teaching character education technique and values found in 'Confession" directed by Tetsuya Nakashima
}

\author{
Cynantia Rachmijati \\ IKIP Siliwangi, West Java, Indonesia. \\ Correspondence: \\ Email: cynantia.rachmijati@gmail.com \\ Revised: \\ 30 July 2020 \\ Accepted: \\ 31 July 2020 \\ Published: \\ 31 July 2020
}

Received:

11 June 2020

\begin{abstract}
"Confession" is a Japanese thriller drama movie about a teacher named Yuko Moriguchi who lost her daughter where she believed that some of her students involved in her daughter's death. The objectives of this research are (1) to explain character education teaching technique (2) to explain the character education values found in the "Confession movie". This research is descriptive qualitative by content analysis. The data source was taken from scene in the "Confession" movie. The object of this research is movie "Confession" directed by Tetsuya Nakashima with 106 minutes running time. The research data are in the form of speech, behaviour, context displayed by the characters through visualization in the film. And analysed based on character education principals teaching and character educational values proposed by Ministry of National Education (2010). The researcher finds 16 data, include 5 data of character education teaching techniques and 11 data of values. Therefore it can be concluded that the character education teaching technique based on this movie are: promoting basic values and explained to the students what makes a good person, be friends with the students and understand their characters, be close to them and talk to them as friends, believe in them and always motivate, praise and encourage them. Whereas the characters values found are: honesty, tolerance, discipline, hard-working, creative, democratic, patriotic, appreciative, peace-loving and social care. It is also noted that movie can be used as aid in teaching character education where it can be obtained through themes, messages, and advice in the values of the movie storyline.
\end{abstract}

Keyword: movie; confession; character education; values

\section{INTRODUCTION}

Parents want nothing more than for their children to grow up into well-mannered individuals and give the proper respect to other people. Which is why character education is an important part in their studies, because success in life does not always rely on academics (Afriana, 2018). The crisis of character that is increasingly endemic among the younger generation, even the previous generation of the birth concerns. Every day, the media is constantly inundated with news stories of crime, murder, increased promiscuity, rampant numbers of violence, adolescent girls, and so on. The case reported in the mass mediated is one of the evidences why national character increasingly worrying (Anika, 2016). 
Rachmijati, C. (2020). An analysis of teaching character education technique and values found in 'Confession" directed by Tetsuya Nakashima. Journal of Advanced Multidisciplinary Research, 1 (1), 1021. DOI: http://dx.doi.org/10.30659/JAMR.1.1.10-21

Education is a system that is organized and has quite a broad mission, that is, everything that is related to physical development, health, skills, thoughts, feelings, volition, social to the issue of belief or faith. This shows that the school as a formal educational institution has a fairly heavy burden in carrying out the educational mission. The more so when linked to the rapid changes of the times these days are very influential on the behavior and development of students. In relation to character education, the Indonesian people really need large and high-quality human resources to support the implementation of development programs properly. This is where quality education is needed, which can support the achievement of the ideals of the nation in having quality resources.

This is in accordance with Law No. 20 of 2003 concerning the National Education System in Article 3, which states that national education functions to develop capabilities and shape the dignified character and civilization of the nation in order to educate the nation's life. National education aims to develop the potential of students to become human beings who have faith and are devoted to God Almighty, have good character, are healthy, knowledgeable, capable, creative, independent, and become democratic and responsible citizens.

In today's culture, teachers play a significant role in either directly or indirectly shaping the character of their student. The value of character is relevant today as cultivation of character is believed to be connected to individuals who flourish and are well-rounded. Governments mandate that children not only receive academic education but also character education. Other countries, such as China, Canada, Korea, and Japan also include character education within their national curriculum. The three approaches to character education, including (a) traditional character education, (b) rationalist or contemporary approach, and (c) emotional approach (Nucci, Narvaez, \& T, 2014). For emotional approach usually the character education implementation used movies because when students view movies for homework, they are encouraged to watch it critically and focusing on character development and relationships, not just the plot of the movie (Hesley \& Hesley, 2001).

Teaching well means addressing a set of objectives, for a particular group of students, at a certain point in the school year, with certain resources, within a particular time frame, in a particular school and community setting. Therefore, Teacher needs to conduct and manage the class to create the best teaching and learning situation (Crawford, Saul, Mathews, \& Makinster, 2005).

This condition it seem with the condition in this "Confession" Japanese movie where Moriguchi as the homeroom teacher faced some problems in the class such as: the students can pay attention in the classroom because they are consisting from different background, most of the students disrespect her as a teacher and also there's bullying happening in the class. Hence, she uses some character education teaching technique to attract the students ${ }^{\text {ee }}$ attention. The important thing is she as a teacher always tries to put her best as in similar position with the students.

Literature and films are art products that contain facts of humanity. Both of these art products are loaded with character education which is very important for the 
community, especially students to form positive mental development. The use of movie can be used as aid in teaching learning process and also as aid for teaching character education. Movie used audio and visual to attract the students' attention. Moreover, the students can take messages from the media. Watching movies can be an entertaining and motivating activity for the students.

The objectives of this research are: (1) to explain character education technique used by the main character in the Confession movie. (2) to explain the character values found in the Confession movie. "Kokuhaku" is Japanese movie entitled "Confession" in English. A psychological thriller movie where it was shortlisted as Japan's entry for the Best Foreign Language Film Academy Award and also the $7^{\text {th }}$ highest grossing movie in Japan in 2010 and (IMDbPro, 2010). "Confession" portrayed the image of education in Japan where the main key of the student character building lay in the hand of their homeroom teacher. The message of the student's characters and character building explicitly conveyed through Moriguchi's line in the classroom scene," "Those who are weak of heart will in turn hurt those who are even weaker than them. For those who have been hurt, there are two choices: to choose to endure it, or to choose death. But no, you don't live in such a small world as that. If the place you are in now is painful, isn't it better to take refuge somewhere else?". This line describing that in life there will be hardships and obstacles. Some who are just not confident enough will be facing this life in fear and hide away. But those who are strong and confident, will go on through this life no matter what. But again, the first line which clearly describing "bullying" as the resort for those who see themselves as strong but do not have great characters.

Social studies professors and authors William Benedict Russell III and Stewart Waters note in their book Reel Character Education: A Cinematic Approach to Character Development that movie plays a significant role in our lives and pop culture, often provoking meaningful inquiry regarding social issues, personal values, and moral dilemmas. Thus, movie can serve as a powerful teaching tool to assist youth, in particular, in developing various character strengths and making positive decisions and therefore it can be concluded that movie can be used as character educational tool as well (Wright, 2015).

Character education in the era of the information age increasingly plays an important role in preparing future generations of strong children. The character education contribution is expected that the generation of the nation's children can grow and develop the reliability of their character so that they can filter out any information and internalization that is feasible to live in which information categorized as "trash" to be avoided, discarded, and put aside. Without good handling, the character of the nation and especially the younger generation will not be directed, aspects of humanity will be destroyed, and morals are not dignified as humans. Therefore, character education is one of the main targets in the effort to revitalize the implementation of learning systems in Indonesia. Other revitalization targets include (1) curriculum, (2) ICT-based learning materials, (3) entrepreneurship, (4) alignment, and (5) evaluation (Yahya, 2018).

Education in schools will run smoothly, if in practice pay attention to several principles of character education. The Ministry of National Education (Kebudayaan, 
Rachmijati, C. (2020). An analysis of teaching character education technique and values found in 'Confession" directed by Tetsuya Nakashima. Journal of Advanced Multidisciplinary Research, 1 (1), 1021. DOI: http://dx.doi.org/10.30659/JAMR.1.1.10-21

2010) provides the following principle recommendations for creating effective character education; a. Promoting the basic values of ethics as a basis for character b. Identify the character comprehensively so that it includes thoughts, feelings and behavior c. Use a sharp, proactive and effective approach to building character. d. Creating a school community that cares. e. Provide opportunities for students to show good behavior; $f$. Has a meaningful and challenging curriculum that values all students, builds their character, and helps them succeed. g. Strive for self-motivation growth in students. $h$. Enabling all staff throughout the school staff as a moral community who share responsibility for character education and are loyal to the same basic values. $i$. There is a division of moral leadership and broad support in building character education initiatives.

Character education is a term which is in broad scope and difficult to define. It is an umbrella many aspects of and under "ethic or moral. Kemendikbud (Farid, 2018) explains this umbrella is wider and inter-disciplinary of knowledge. Students should have desire in learning character; they should have something to learn after teaching and learning process. The focus is not just synthesizing teaching and learning process, but students should find what is behind life-lesson. Teachers should be facilitators not guiders. The ideal character of Indonesian students are they have to be discipline, care with others, be concerned with nature, honest, forgive others, and obey every single rule from parents. This character is so difficult to explain using speech. It needs an authentic example. That is why, students should watch movie, which has those kind characters. It is certainly worth noting that given through the help of cinema (such as films, videos, musical dramas, soap operas and so on), students have the opportunity to explore, imagine, and challenge their creativity to appreciate literary works and capture the values conveyed by authors through the message of the story (Elkins, 2016).

Considering that character is developed through interaction in community, character education is inserted in the Indonesian school curriculum. Therefore, The Indonesian Ministry of National Education proposed 18 characters values that should be developed in all sectors of education in order to instil good character. The values proposed by the ministry are religiosity, honesty, tolerance, discipline, hard-working, creative, autonomous, democratic, curiosity, nationalism, patriotic, appreciative, friendly/ communicative, peace-loving, bibliophile, nature loving, social care, and responsibility (Kemdiknas, 2010).

\section{METHOD}

This type of research is descriptive qualitative research to reveal facts, events, and circumstances of phenomena contained in the object of film research resulting from the exploitation of literary works. This study applies qualitative research methods by analyzing media content. Qualitative research methods are often called naturalistic research methods because their research is conducted in natural conditions; referred to as a qualitative method, because the data collected and analysis are more qualitative (Sugiyono, 2015). The approach is done by content analysis. The research data is in the form of speech, behaviour, context, which are displayed by the characters through 
visualization in the film. The primary source of this data in this reseach is the movie "Kokuhaku" with "Confession"as it's English title. "Confession" is a 2010 Japanese movie based on the Kanae Minatos' novel with 106 minutes running time and produced by DesperaDo production house. The data is presented in forms of sentences, narrations , dialogues and scenes taken through out the movie. The procedure of data collection is done by observing, watch, repeatedly and notes the aspects that are relevant to the purpose of the research with the main instruments by researchers who are equipped with concepts and aspects of character education as software. Data analysis was carried out by classification based on character problems, tabulation, and descriptive classification qualitative, then interpretations is carried out through inference by paying attention to research problems and data findings during the data collection process. Furthermore, the data is interpreted through literary characterization (Monderop, 2005) .

\section{RESULTS AND DISCUSSION}

The movie "Confession" started with the scene of Yuko Moriguchi, a junior high teacher, announces she will resign. She reveals that her daughter, Manami, was killed by two pupils in her class, whom she dubs "Student A" and "Student B". Her disclosure of their behaviour soon reveals their identities, but she recognizes that they will escape punishment as legal minors. Instead, she admits to injecting her dead husband's HIV contaminated blood into the milk cartons that the murderers have just drank from. The rest of the film describes the aftermath of this event in a series of first-person narratives from the two students, Moriguchi, and others.

"Confession" told about main characters life problem and the aftermath after their daughter's teacher killed in an accident. The movie has 4 main characters, they are : Yuko Moriguchi the teacher who lost her mind because her daughter is killed, Shuya Watanabe who is a straight A student who is smart but a loner because his mother left him. The third character is Naoki Shimomura who is a transfer student who only like sport but he can't do it because his grade is below average, on top of that he is also very lonely. The last one is Mizuki Kitahara also known as Lunacy girl, is a girl with a twisted mind who killed her parents using chemical drugs. Mizuki is the outcast in the classroom and she is not friends with any circle in the class. Their belief, values, behaviour and chronicle of their life are describing through sequences of events called "confession", hence the title of the movie.

The first confession is the confession of Yuko Moriguchi, the homeroom teacher who announces that she will resign because her daughter has been killed by her two students. Student A ( who is referring to Shuya Watanabe) and Student B (who is referring to Naoki). But as junior high schoolers, the mind, values and belief of the students are somewhat still simple yet naive. Shuya Watanabe just want recognition and acknowledgment of his friends, Naoki just wish to be accepted in the society and Mizuki just still struggling and adapting to understand life. While Wherther, as the new homeroom teacher is being enthusiastic and wish to be accepted by his students. The 
Rachmijati, C. (2020). An analysis of teaching character education technique and values found in 'Confession" directed by Tetsuya Nakashima. Journal of Advanced Multidisciplinary Research, 1 (1), 1021. DOI: http://dx.doi.org/10.30659/JAMR.1.1.10-21

whole characters are easily related to real life where if there are no tolerance, communication and understanding in a small society of a school and classroom - many misunderstandings may happen. And many mishaps and events may cause into chaos and most of all, fail of education especially in the character education department.

Below are some characters' utterances which explicitly convey their beliefs regarding ideas of education, life, moral and character building:

a. Moriguchi (to students): you can become quite self-absorbs and completely wrapped up in your own little worlds. It is easy to forget what it means to simply to live. I'm going to make sure none of you ever use words like "I want to die" so lightly again

b. Moriguchi (on students behaving badly): I remember it dawning on me that the only punishment children ever have to deal with are a few extra laps or having to clean the pool

c. Moriguchi (on punishment): if you're repaying hatred with hatred then your mind will never be at ease. They're sure to see the error of their ways one day. Let's believe in them. For in their redemption lies your recovery.

d. Moriguchi (on character education technique): "There were two rules I chose to work by. One, address the students politely. Two, do my best to place myself on the same level of them. Speak with them as I'd like to be spoken to. Be friends with them as if we were friends, talking to them about anything they wanted".

e. Werther (on encouraging students): I want to be like a big brother to you all. You all posses unique, individual abilities. I want to see all continue to polish those abilities because I am watching you

f. Mizuki (on life): is life a heavy burden to bear? Life isn't worth a thing

g. Mizuki (on her classmate): we all possess unique abilities. The ability to bully those weaker than you. The ability to forget things you don't want to face.

h. Watanabe (on life): Even if you are recognized for doing good stuff, nobody pays attention. All I wanted was for someone to recognize me.

i. Naoki (on life): I wanted to be friends with you, I didn't have any friends since nobody acknowledge me before.

\section{Discussion}

The findings of this research have been collected from watching "Confession" movie. There are two research findings in this research. First, the researcher found 5 data of character education teaching techniques. Second, the researcher also found 11 data of character values. Thus, the whole data are 16 data.

For character education teaching technique based on Ministry of National Education's principle of character education teaching (Kebudayaan, 2010) therefore it was finding there were 5 data which is along with the character education principles:

1. Promoting the basic values of ethics as a basis for character 
Both Moriguchi and Werther as the homeroom teacher always try their best to tell the students that they need to be good person and good people with characters. As Moriguchi said to her students that,"You can become quite selfabsorbs and completely wrapped up in your own little worlds. It is easy to forget what it means to simply to live. I'm going to make sure none of you ever use words like "I want to die" so lightly again". She also considering how punishment and rewards should be given so the students can learn from the mistake. This show in her utterance which said," I remember it dawning on me that the only punishment children ever have to deal with are a few extra laps or having to clean the pool". Werther also encouraged the students to study hard and not to be bully and to be friends with everyone.

2. Identify the character comprehensively so that it includes thoughts, feelings and behavior

Moriguchi's technique on this is to be friends with the students in order to make the students feel comfortable with the students. This show on her utterance which," There were two rules I chose to work by. One, address the students politely. Two, do my best to place myself on the same level of them. Speak with them as I'd like to be spoken to. Be friends with them as if we were friends, talking to them about anything they wanted". On here she clearly regards them and considers students' feelings, thoughts and behaviours.

3. Use a sharp, proactive and effective approach to building character.

On this, Moriguchi believed in rewards and punishment system therefore the students can learn and understand when they made mistakes. This showed on her utterance which Moriguchi said,"If you're repaying hatred with hatred then your mind will never be at ease. They're sure to see the error of their ways one day. Let's believe in them. For in their redemption lies your recovery". Therefore, she didn't believe in being angry or lash out, but to understand and let the students find ways in their error.

4. Provide opportunities for students to show good behavior;

Werther the substitute homeroom teacher always try to be friendly with the students and he said that,"I want to be like a big brother to you all" while encouraging the students to work hard and be friends even with Mizuki, Watanabe and Naoki the students who were being bullied.

5. Strive for self-motivation growth in students.

Werther also always try to spread positive message and being a happy person in general which can be seen on his utterance," You all possess unique, individual abilities. I want to see all continue to polish those abilities because I am watching you" to encourage the students to raise their grades and talents in general.

In this discussion the values of character education will be discussed by referring to the existing theories in accordance with the problem under study. The value of character education found in this study was seen based on the formulation of the value of character education from the Ministry of National Education.

\section{Character value: Honesty}


Rachmijati, C. (2020). An analysis of teaching character education technique and values found in 'Confession" directed by Tetsuya Nakashima. Journal of Advanced Multidisciplinary Research, 1 (1), 1021. DOI: http://dx.doi.org/10.30659/JAMR.1.1.10-21

Data scene: 47.48

Honesty is behavior that is based on efforts to make himself as a person who can always be trusted in words, actions, and work (Kebudayaan, 2010). The honesty value found on Shuya Watanabe's character where he admitted to Mizuki that he actually didn't have aids. They were bullied by the classmates and he even rumoured to have aids. Therefore, he told her in the evening after class near the bridge that he actually didn't have aids. He even brought her the examination paper to proof that to her. Mizuki believed him. His honesty showed through the bravery of telling the truth even though he was being bullied by his classmates continuously.

\section{Character value: Courage}

Data scene: 41.10

Courage is the act of bear the risk of the act when it was done (Kebudayaan, 2010). The courage value found on Mizuki's character where she finally lashed out at Werther the homeroom teacher for lacking attention on their student's situation in the classroom. Werther had this relentless approach of visiting student's home which Mizuki found annoying and to no avail. She told Werther this opinion to made Werther opened his eyes and realize the situation. She was being courage and explained Werther the substitute home teacher that his teaching style was wrong.

\section{Character value: Peace loving}

Data scene: 22.10

Peace loving is attitudes, words and actions that caused people feel happy and secure for his presence (Kebudayaan, 2010). The peace-loving value found on Naoki's character where he finally befriended with Watanabe and happy that he was called mature. Naoki's lonesome character was finally happy after struggling with school and gymnastic team and he was finally happy after Watanabe approached him and they became friends. After they became friends they talked and hang out a lot at Watanabe's place. Watanabe was happy to have met Naoki and they always shared togetherness while working their homework together at Watanabe's and that Watanabe enjoyed Naoki's presence.

\section{Character value: Self-disciplined}

Data scene: 20.29

Self-disciplined value is an attitude which shows orderliness action and obey to every law and rule (Kebudayaan, 2010). The self-discipline value found on Watanabe's character where he always studies diligently and always get a good rank despite being bullied by his classmates. Watanabe wished to be as smart as his mother who leaved him when he was younger to be a scientist. Therefore Watanabe studied hard in order to be a scientist just like her. Almost in every scene Watanabe always reading or holding a book or bring a book. He always strives to be better, to be a good student and thus spending most of his time by studying, reading and on its own accord of self-discipline because his parents never reminded him to study.

\section{Character value: Appreciative}

Data scene: 58.59 
Appreciative is an attitude and behaviour that encourage to make something useful for society and sincerely admit and respect the achievement of others (Kebudayaan, 2010). The appreciative value found on Mizuki's character where she saw the tv news and witness news on Naoki's murder charge. Mizuki's soft hearted and good observation lead her to understand her classmate's character better than Watanabe and Naoki. She believed in second chances and that everyone just needs to be understood. Even though she herself was being bullied, but she was appreciative on her friends who were there for her and thus opened up a new relationship and understanding with others as well.

\section{Character value: Tolerance}

Data scene: 1.12 .00

Tolerance is an attitude and behaviour about respecting the differences such as religion, tribe, ethnicity, opinion, attitude and behaviour of others (Kebudayaan, 2010). The tolerance value found on Mizuki's character where she befriended Watanabe and spent some times together on his warehouse. She was being tolerance towards her friends even though he was being mean towards her and she kept holding her ground.

\section{Character value: hardworking}

Data scene: 1.16 .35

Hardworking is an attitude which shows a real effort in solving the problem and homework also finishing every job well (Kebudayaan, 2010). The hardworking value where found on Watanabe's character where he kept studying hard and re-read the books which his mother left him because he wanted to be a good student. In fact, he did become a straight A student despite being bullied by his classmates.

\section{Character value: Social care}

Data scene: 1.14 .25

Social care is attitudes and actions which shows efforts to always give helps to others who are in need (Kebudayaan, 2010). The social care value found on Naoki's character where he was happy that Watanabe would like to be friend with him. Naoki's bright and pure personality shone through where he was with Watanabe especially when they hang out together after class. He also listened to his worries and tried hard to be a good friend and always be there for him.

\section{Character value: Democratic and patriotic}

Data scene: 1.19 .00

Democratic and patriotic value can be seen as the way of thinking, behaving, and acting which shows high royalty, caring and high appreciation of language, environment, social, culture, economy and politic of their nation (Kebudayaan, 2010). The democratic and patriotic value found on Moriguchi's character almost throughout the entire movie but mostly on the scene where she tried to reassembled Watanabe's bomb in the school and reprimanded him that what he was doing was wrong. Moriguchi tried to fought for the truth regarding to what happened to her daughter's death and therefore he believed that Watanabe and Naoki as the suspects who killed her daughter needed to be reprimanded of their wrongdoings. Moriguchi portrayed democratic and patriotic value by showing the students the government rules, reprimanding their students for their 
Rachmijati, C. (2020). An analysis of teaching character education technique and values found in 'Confession" directed by Tetsuya Nakashima. Journal of Advanced Multidisciplinary Research, 1 (1), 1021. DOI: http://dx.doi.org/10.30659/JAMR.1.1.10-21

wrong doings and even consult the school regarding school rules that should be corrected to make students be even better.

\section{Character value: Creative}

Data scene: 17.44

Creative is about thinking and doing something to make new ways or new result of something that you already have (Kebudayaan, 2010). The creative character value found on Watanabe's character where he joined a science fair and he won by experimenting a thief wallet product. He made the wallet based on his experience and observation, then he made the prototype. Then he tried to consult the end product with the teacher and resulting him won the science fair with his innovation.

\section{Character value: Responsibility}

Data scene: 1.15 .23

Responsible is an attitude which shows sincerity in doing their job and obligation that should be done toward themselves, society, environment, country and to God (Kebudayaan, 2010). The responsibility value found on Naoki's character where after he killed his mother he was willingly captured by the police as the sign of being responsible for his wrongdoing.

From the explanation above, it can be seen in the following data tabulation of the character education values reflected on the movie characters:

Table 1. Data tabulation of the character education values reflected on the movie characters

\begin{tabular}{lllc}
\hline No & Value of education & Character & Sequence/Data scene \\
\hline 1 & Honesty & Watanabe & 47.48 \\
\hline 2 & Courage & Mizuki & 41.10 \\
\hline 3 & Peace loving & Naoki & 22.10 \\
\hline 4 & Self discipline & Watanabe & 20.29 \\
\hline 5 & Appreciative & Mizuki & 58.59 \\
\hline 6 & Tolerance & Mizuki & 1.12 .00 \\
\hline 7 & Hardworking & Watanabe & 1.16 .35 \\
\hline 8 & Social care & Naoki & 1.14 .25 \\
\hline 9 & Democratic and patriotic & Moriguchi & 1.19 .00 \\
\hline 10 & Creative & Watanabe & 17.44 \\
\hline 11 & Responsibility & Naoki & 1.15 .23 \\
\hline
\end{tabular}

Therefore, from the whole 18 characters education values proposed by Ministry of National Education in the "Confession" movie found 11 values which reflected by the the form of speech, behaviour, context and characterization of the characters.

\section{CONCLUSION}

Character is also known as values, goodness and morals. In short, education has had two goals: to help people become smart and to help them become good. Based on the research questions it was found 16 data which answered the research question. The character education teaching technique on the "Confession" movie are : promoting the basic values of ethics as a basis for character, identify the character comprehensively so that it includes thoughts, feelings and behavior, use a sharp, proactive and effective 
approach to building character also provide opportunities for students to show good behavior and the last was strive for self-motivation growth in students. It can be concluded that the character education teaching techniques that we can implement in the classroom based on the research findings are:

1. Promoting basic values and explained to the students what makes a good person

2. Be friends with the students and understand their characters

3. Be close to them and talk to them as friends

4. Believe in them

5. Always motivate, praise and encourage them

Whereas the characters values found are: honesty, tolerance, discipline, hardworking, creative, democratic, patriotic, appreciative, peace-loving and social care. It is also to be noted that the use of movie can be used as aid in teaching learning process and also as aid for teaching character education. Movie used audio and visual to attract the students' attention. Character education can be obtained through themes, messages, and advice in the values of the storyline.

\section{REFERENCE}

Afriana. (2018). Analysis of students' perspective toward implementation of character education. Journal of English Education Vol 4 No 2, 76-92.

Anika, D. M. (2016). Development of character education based on local wisdom in indingenous people tengahan Sedangagung. Journal of Education, Teaching and Learning Vol 1 No 2, 66-70.

Campbell, V., \& Bond, R. (1982). Evaluation of character education curriculum. Mcleland: Irvinton Publisher.

Crawford, A., Saul, W., Mathews, S., \& Makinster, J. (2005). Teaching and learning strategies for the thinking classroom. New York: International Debate Education Association.

Elkins, D. (2016). Teaching literature. Ohio: Charles Merrill and Publishing Co.

Farid, H. (2018). Gerakan penguatan pendidikan karakter melalui sejarah. Retrieved from Kemendikbud: cerdasberkarakter.kemendikbud.go.id/?p=1096

Hesley, J., \& Hesley, J. (2001). Rent two films and let's talk in the morning : Using popular films in psychotherapy. New York: John WIley and Sons Inc.

IMDB. (n.d.). IMDB. Retrieved from IMDB: https://www.imdb.com/title/tt1590089/

IMDbPro. (2010). IMDb. Retrieved from Internet Movie Data Base: https://www.imdb.com/title/tt1590089/?ref_=ttgf_ql

Kebudayaan, D. P. (2010). Pembinaan pendidikan karakter di Sekolah Menengah Pertama. Jakarta: Kemendiknas. 
Rachmijati, C. (2020). An analysis of teaching character education technique and values found in 'Confession" directed by Tetsuya Nakashima. Journal of Advanced Multidisciplinary Research, 1 (1), 1021. DOI: http://dx.doi.org/10.30659/JAMR.1.1.10-21

Kemdiknas. (2010). Panduan pendidikan karakter di sekolah menengah pertama . Jakarta: Dirjen Dikdasmen.

Linda, E. (1997). Mengajarkan nilai-nilai kepada anak. Jakarta: Gramedia.

Monderop, A. (2005). Metode karakterisasi telaah fiksi. Jakarta: Yayasan Obor Indonesia.

Nucci, L., Narvaez, D., \& T, K. (2014). Handbook of moral and character education. New York: Routledge.

Sugiyono. (2015). Metode penelitian kuantitatif, kualitatif dan R\&D. Bandung: Alfabeta.

Sutarman, Hermawan, H., \& Ahmad. (2017). Character education to build personal learners tough. Journal of Research Method in Education Vol 7 No 1, 59-63.

Wright, C. (2015). Edutopia. Retrieved from Edutopia : Character education: https://www.edutopia.org/blog/reel-character-film-enhances-sel-christina-wright

Yahya, M. (2018). Era Industri 4.0 : Tantangan dan peluang perkembangan pendidikan kejuruan Indonesia. Makasar: Universitas Negeri Makasar. 